\title{
What Host Factors Affect Aseptic Loosening After THA and TKA?
}

\author{
Jeffrey J. Cherian DO, Julio J. Jauregui MD, \\ Samik Banerjee MD, Todd Pierce MD, \\ Michael A. Mont MD
}

Received: 19 November 2014 / Accepted: 18 February 2015/Published online: 26 February 2015

(C) The Association of Bone and Joint Surgeons (B) 2015

\begin{abstract}
Background Aseptic loosening is the most common cause for revisions after lower-extremity total joint arthroplasties, however studies differ regarding the degree to which host factors influence loosening.

Questions/purpose We performed a systematic review to determine which host factors play a role in the development of clinical and/or radiographic failure from aseptic loosening after (1) THA and (2) TKA.

Methods Two searches on THA and TKA, respectively, using four electronic databases (EMBASE, CINAHL Plus, PubMed, and Scopus) were conducted. We identified a total of 209 reports that encompassed nine potential host factors affecting aseptic loosening. Inclusion criteria for consideration of scientific clinical reports were that 20 or more patients were involved, with more than 1-year followup, with at least three studies pertaining to each factor, and at least six of the Methodological Index for Non-randomized Studies criteria met, and with raw data for odds ratio (OR)
\end{abstract}

Each author certifies that he or she has no commercial associations (eg, consultancies, stock ownership, equity interest, patent/licensing arrangements, etc) that might pose a conflict of interest in connection with the submitted article.

All ICMJE Conflict of Interest Forms for authors and Clinical Orthopaedics and Related Research ${ }^{\circledR}$ editors and board members are on file with the publication and can be viewed on request.

Each author certifies that his or her institution approved or waived approval for the reporting of this case and that all investigations were conducted in conformity with ethical principles of research.

J. J. Cherian, J. J. Jauregui, S. Banerjee, T. Pierce,

M. A. Mont $(\square)$

Rubin Institute for Advanced Orthopedics, Center for Joint Preservation and Replacement, Sinai Hospital of Baltimore, 2401 West Belvedere Avenue, Baltimore, MD 21215, USA e-mail: mmont@lifebridgehealth.org calculations. Twenty-one studies (16 THA studies with 45,779 hips and five TKA studies with 288 knees, respectively) were used to calculate weighted OR and CIs (using the random effects theory) and study heterogeneity for four different host factors in THAs (male sex, high activity level, obesity defined as BMI $\geq 30 \mathrm{~kg} / \mathrm{m}^{2}$, and current or former tobacco use) and one factor in TKA (BMI $\geq 30 \mathrm{~kg} / \mathrm{m}^{2}$ ), which were placed in a forest plot.

Results For THA, male sex (OR, 1.39; 95\% CI, 1.22-1.58; $\mathrm{p}=0.001$ ) and high activity level (University of California Los Angeles [UCLA] activity score $\geq 8$ points; OR, 4.24; 95\% CI, 2.46-7.31; $\mathrm{p}=0.001$ ) were associated with aseptic loosening. However, obesity (OR, 1.01; 95\% CI, 0.73-1.40; $\mathrm{p}=0.96)$, and tobacco use (OR, 1.96; 95\% CI, 0.43-8.97; $\mathrm{p}=0.39$ ) were not associated with an increased risk of aseptic loosening after THA with the numbers available. For TKA, we found no host factors associated with loosening. In particular, obesity (BMI $\geq 30 \mathrm{~kg} / \mathrm{m}^{2}$ ) was not associated with aseptic loosening with the numbers available (OR, 2.28; 95\% CI, 0.60-8.62; $\mathrm{p}=0.22$ ).

Conclusions Patients undergoing a lower-extremity total joint arthroplasty who engage in impact sports should be counseled regarding their potential increased risk of aseptic loosening; however, given the weak evidence available, we believe that higher-level studies are necessary to clearly define the risk factors, particularly with newer-generation constructs.

Level of Evidence Level IV, therapeutic study.

\section{Introduction}

A lower-extremity total joint arthroplasty has been one of the most successful orthopaedic procedures with multiple reports describing greater than $90 \%$ survivorship at 15 to 
20 years $[1,26,40]$. Despite the clinical success of the arthroplasties, aseptic loosening is one of the major causes of failure [29, 45]. Aseptic loosening has been reported to be one of the most common causes for revisions, accounting for almost 55\% of hip [47] and $31 \%$ of knee [49] revisions. As such, it is imperative to optimize primary outcomes in total joint arthroplasties and to avoid the difficulties and complication rates that can be found with revisions.

Various theories have been proposed for the cause of aseptic loosening which have been based predominantly on empiric observations, experimental and clinical studies, and anecdotal reports $[18,33,34]$. One of the most commonly proposed theories is that the development of excess-wear particles produces a proinflammatory state [18], which leads to increased osteoclast differentiation and macrophage production. This ultimately leads to local osteolysis and aseptic loosening around the prosthesis [34]. The final pathways to progressive particle wear leading to aseptic loosening and construct failure are driven by the inflammatory-mediated osteolysis. Additionally, several other factors can affect patient susceptibility to aseptic loosening after lower-extremity total joint arthroplasty. The factors generally can be divided into host-, genetic-, surgical-, and prosthesis-related factors; however, there is no consensus regarding the degree to which host factors influence aseptic loosening.

Therefore, we performed a systematic review to identify various host factors that have been reported to be associated with aseptic implant loosening, thereby decreasing duration of implant survival. Specifically, we asked: What host factors have been consistently reported to be associated with the development of clinical and/or radiographic failure owing to aseptic loosening in patients who underwent (1) THA and (2) TKA?

\section{Methods}

Two of the coauthors (JJC, SB) performed a thorough literature search using the EMBASE, CINAHL Plus, PubMed, and Scopus electronic libraries. All studies published from January 1976 to September 2013 were evaluated using a combination of the Boolean search strings Wear*, Aseptic*, Loosening*, Revision*, Risk*, Osteolysis*, Knee*, and Hip* to identify host factors associated with aseptic loosening in THA and TKA. Using our search criteria, 715 reports were identified. The collected reports identified nine host factors associated with increased rates of aseptic loosening, including patient age, sex, BMI, activity levels, social habits (consuming alcohol and tobacco use), preoperative diagnoses (diabetes, rheumatoid arthritis, osteonecrosis), and bone geometry and quality.
We performed a secondary structured search of the same databases between January 1976 and September 2013 to identify reports that focused on each host factor associated with aseptic loosening. We used a combination of the Boolean search strings knee[title], hip[title], arthroplast*[title], tobacco[title], smok*[title], replace*[title], alcohol*[title], cigarette[title], bone[title], loose*[title], BMI[title], obes*[title], age[title], sex[title], gender[title], geometry[title], activi*[title], aseptic[title], loosening [title], wear[title], diabet*[title], quality[title], type A [title], type B[title], type C[title], Singh index[title], Dorr[title], rheum*[title], and osteonecrosis[title] to identify all reports on the factors related to aseptic loosening.

We considered for inclusion: (1) scientific clinical reports describing the effect of various host factors for aseptic loosening; (2) studies with outcomes for 20 or more patients; (3) clinical studies that had three or more reports on specific host factors for knees and hips; and (4) studies with more than a 1-year minimum followup. We excluded: (1) case reports; (2) review reports; (3) clinical studies reporting outcomes for less than 20 patients; (4) less than a 1-year minimum followup; (5) basic science studies; (6) reports focusing on preoperative diagnoses (diabetes, rheumatoid arthritis, osteonecrosis,) resulting from previous systematic reviews published on these topics, in that we considered the current literature too extensive to include such in a single report; (7) reports not written or translated into English; and (8) reports on arthroplasties using metal-on-metal implants. Additionally, we excluded studies that evaluated: (1) surgical factors; (2) medication use; (3) implant factors; (4) genetic polymorphisms; (4) instability; and (5) endotoxins in the role of excess aseptic loosening. The initial search resulted in 3405 reports for evaluation. Through a title and abstract review, using the additional exclusion criteria, we disqualified 3196 studies, resulting in 209 reports that were found potentially relevant. The 209 reports were recovered in full and examined in detail by two authors (SB, JJC) independently, and studies included in our final analysis were selected by a consensus decision. The content of each article was critically analyzed to avoid including multiple reports with the same patient population published by the same author. When such a situation was encountered, the study with the larger group of patients and/or the longer followup was included in the analysis. A third author's (JJJ) opinion was sought when a consensus decision could not be reached, which resulted in 63 studies for further analysis, and bibliographies for these reports were individually searched to extract additional studies for the final analysis. This resulted in an additional 21 studies leading to a total of 84 reports.

Additionally, each manuscript was assessed using the Methodological Index for Non-randomized Studies 
(MINORS) criteria [50]. The MINORS criteria scoring was modified to an all-or-nothing scale where studies that adequately reported an index of the MINORS criteria received 1 point [50]. This approach has been used and validated [55]. Studies that did not report or inadequately reported one of the criterion received no points, and all studies that had less than 6 points were excluded. A modified MINORS then was used because of the inherit difficulty in applying the traditional MINORS scoring scale with the loss to followup for our included studies. For example, we found several studies with substantial patient loss to followup, and the standard MINORS scoring system would assign 1 point to the study for reporting it. Because there were a large number of studies with a loss to followup-markedly greater than 5\%-using an allor-nothing scoring system allowed for more appropriate evaluation of all relevant studies. Furthermore, we did not include studies that had a loss to followup greater than $25 \%$. After assessing each report for MINORS criteria, a total of 60 studies had at least 6 points, thereby qualifying for inclusion in our review.

All studies were analyzed by three of the authors (SB, JJC, JJJ) for study type, publication year, mean age (range), mean followup (range), aseptic loosening rate, odds ratio (OR) for aseptic loosening, and level of evidence. Of the studies that met our modified MINORS criteria, 21 contained the raw data that allowed us to calculate a weighted OR of aseptic loosening after total joint arthroplasty. For THA, the OR of four separate host factors, which included male sex (three studies on 40,615 hips) [4, 16, 37], high activity level (University of California Los Angeles [UCLA] activity score $\geq 8$ points) (three studies on 178 hips) $[14,30,42]$, tobacco use (three studies in 2040 hips) [20, 21, 35], and obesity (seven studies in 2946 hips) [2, 15, 28, 31, 34, 37, 51] were calculated (Fig. 1). For TKA, we were able to calculate a weighted OR of aseptic loosening in patients with a BMI of $30 \mathrm{~kg} / \mathrm{m}^{2}$ or greater (five studies in 288 knees) [11, 13, 27, 36, 39] (Fig. 1).

All outcome metrics and raw data were tabulated in an Excel spreadsheet (Excel 2011; Microsoft Corporation, Redmond, WA, USA). In studies reporting raw data for each cohort, MedCalc ${ }^{\circledR} \quad$ MedCalc $^{\circledR}$ Software, Osteen, Belgium) was used to calculate a weighted OR, 95\% CIs, and p values. Additionally, MedCalc ${ }^{\circledR}$ was used to create multiple forest plots and to calculate the total random effects, which assumed variety in the effects of the selected studies and thereby addresses study heterogeneity. As such, wider CIs were allowed because studies with more statistical power carried more weight in determining the weighted OR with their CIs. Furthermore, this allowed for an accurate depiction of the power of this study. A p value less than 0.05 was used to determine statistical significance.

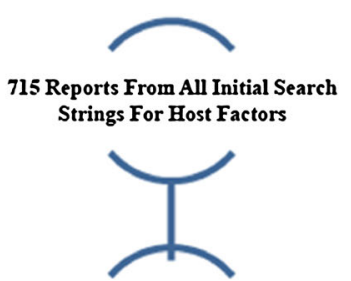

9 Host Factors Identified

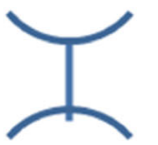

3405 Reports From All Secondary Search Strings of Host Factors

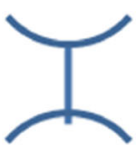

2463 Reports

Boolean Search String After Exclusion

of Preoperative Diagnosis
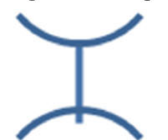

209 Articles After Title And Abstract Review

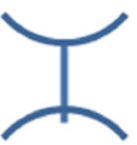

63 Articles Met Exclusion Criteria

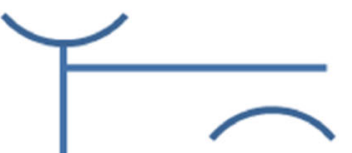

+21 Articles From Reference Title Review

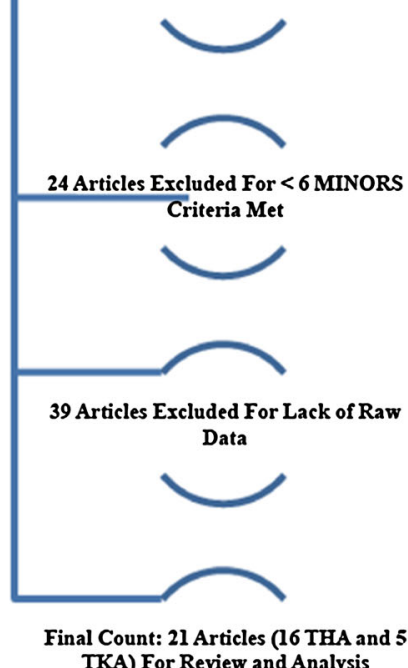

TKA) For Review and Analysis

Fig. 1 Our literature search showed a total of 21 reports for analysis (MINORS $=$ Methodological Index for Non-randomized Studies). 
Table 1. THA sex studies

\begin{tabular}{|c|c|c|c|c|c|c|c|c|}
\hline Study & LOE & MINORS & $\begin{array}{l}\text { Number } \\
\text { of hips }\end{array}$ & $\begin{array}{l}\text { Mean age, } \\
\text { years } \\
\text { (range) }\end{array}$ & $\begin{array}{l}\text { Mean } \\
\text { followup, } \\
\text { years (range) }\end{array}$ & $\begin{array}{l}\text { Revision } \\
\text { because of } \\
\text { wear }(\%)\end{array}$ & $\begin{array}{l}\text { Overall aseptic } \\
\text { loosening rate }\end{array}$ & Outcomes \\
\hline $\begin{array}{c}\text { Inacio } \\
\text { et al. } \\
{[16]}\end{array}$ & III & 9 & 35,140 & $67(20-90)$ & $3(1.3-5.1)$ & 3.4 & 10.6 & $\begin{array}{l}\text { Women had a } 29 \% \text { higher risk of } \\
\text { implant failure than men }\end{array}$ \\
\hline $\begin{array}{l}\text { Munger } \\
\text { et al. } \\
\text { [37] }\end{array}$ & III & 7 & 725 & $65(\mathrm{NR})$ & NR & NR & NR & $\begin{array}{l}\text { Women had significantly lower risk of } \\
\text { aseptic loosening (OR, 0.4; } \\
\text { p }<0.001)\end{array}$ \\
\hline $\begin{array}{l}\text { Bordini } \\
\text { et al. } \\
{[4]}\end{array}$ & IV & 6 & 4750 & NR & NR & 2.8 & NR & $\begin{array}{l}\text { Stem survivorship negatively affected } \\
\text { by male } \operatorname{sex}(p=0.02)\end{array}$ \\
\hline
\end{tabular}

MINORS = Methodological Index for Non-randomized Studies; OR = odds ratio; LOE = level of evidence; NR = not reported.

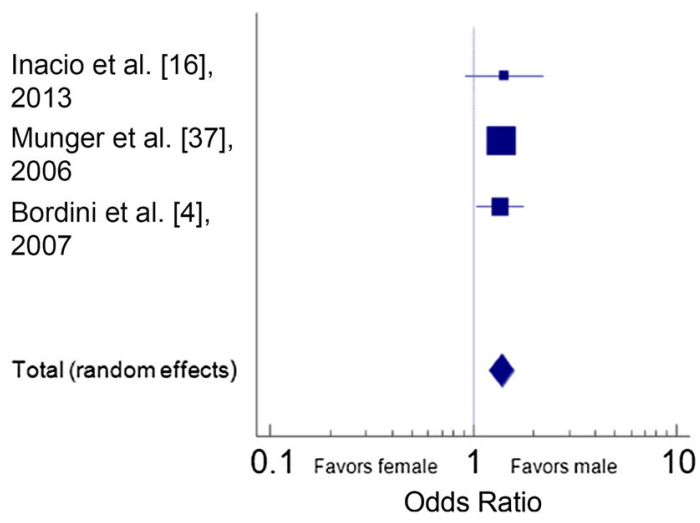

Fig. 2 The forest plot shows the odd ratios $(\mathrm{OR})$ for aseptic loosening for male sex after THA (OR, 1.39; 95\% CI, 1.22-1.58; $\mathrm{p}=0.001)$.

\section{Results}

Host factors analyzed in THA were male sex, increased activity level, increased BMI, and tobacco use. Men were more likely to have a diagnosis of loosening than women (OR, 1.39; 95\% CI, 1.22-1.58; p = 0.001) (Table 1; Fig. 2). In addition, patients with high activity levels were more likely to experience loosening compared with patients with medium or low activity levels, (OR, 4.24; 95\% CI, 2.46-7.31; $\mathrm{p}=0.001$ ) (Table 2; Fig. 3). However, patients who had a BMI of $30 \mathrm{~kg} / \mathrm{m}^{2}$ or greater showed no difference with the numbers available in the risk of aseptic loosening compared with patients with a BMI less than $30 \mathrm{~kg} / \mathrm{m}^{2}$ (OR, 1.01; 95\% CI, 0.73-1.40; $\mathrm{p}=0.96$ ) (Table 3; Fig. 4). Similarly, tobacco use (current and former) was not associated with aseptic loosening of the prosthesis with the numbers available (OR, 1.96; 95\% CI, 0.43-8.97; $\mathrm{p}=0.39$ ) (Table 4; Fig. 5).

For patients with a BMI of $30 \mathrm{~kg} / \mathrm{m}^{2}$ or greater and who underwent a TKA, there was no difference with the numbers available in their risk of aseptic loosening compared with patients with a BMI less than $30 \mathrm{~kg} / \mathrm{m}^{2}$ (OR, 2.28; 95\% CI, 0.60-8.62; $\mathrm{p}=0.22$ ) (Table 5; Fig. 6).

\section{Discussion}

Lower-extremity arthroplasty is efficacious and generally results in excellent long-term survivorship; however, aseptic loosening remains a concern. Various host factors have been associated with the development of aseptic loosening, but studies have differed regarding the degree to which host factors influence loosening. Thus, the aim of our systematic review was to identify the host factors associated with aseptic loosening. We found that high activity level and male sex were associated with an increase in aseptic loosening rates after THA, but we found no host factors associated with loosening after TKA.

There were several limitations to our review. Unfortunately, there is a paucity of prospective studies $[14,30]$ 
Table 2. Activity level studies

\begin{tabular}{|c|c|c|c|c|c|c|c|c|c|}
\hline Study & LOE & MINORS & $\begin{array}{l}\text { Number } \\
\text { of hips }\end{array}$ & $\begin{array}{l}\text { Mean age, } \\
\text { years } \\
\text { (range) }\end{array}$ & $\begin{array}{l}\text { Mean } \\
\text { followup } \\
\text { years } \\
\text { (range) }\end{array}$ & $\begin{array}{l}\text { Revision } \\
\text { because of } \\
\text { wear }(\%)\end{array}$ & $\begin{array}{l}\text { Wear } \\
(\mathrm{mm})\end{array}$ & $\begin{array}{l}\text { Overall } \\
\text { aseptic } \\
\text { loosening } \\
\text { rate }\end{array}$ & Outcomes \\
\hline $\begin{array}{l}\text { Ollivier } \\
\text { et al. } \\
\text { [42] }\end{array}$ & III & 7 & 70 & $58(\mathrm{NR})$ & $11(10-15)$ & $20 / 6^{*}$ & 0.145 & 20 & $\begin{array}{l}\text { Practicing high-impact sport increased wear } \\
\text { rate }(\mathrm{p}<0.001) \text {, and decreased } \\
\text { survivorship }(\mathrm{p}<0.001) \text {; OR, } 3.64\end{array}$ \\
\hline $\begin{array}{l}\text { Gschwend } \\
\text { et al. } \\
\text { [14] }\end{array}$ & III & 6 & 50 & $65(47-84)$ & $10(9-12)$ & NR & NR & 6.6 & $\begin{array}{l}\text { Significantly higher wear in very active } \\
\text { patients }(\mathrm{p}<0.05)\end{array}$ \\
\hline $\begin{array}{l}\text { Lübbeke } \\
\text { et al. } \\
\text { [30] }\end{array}$ & IV & 8 & 58 & $68(30-91)$ & $8(4-12)$ & 0.8 & NR & 24 & $\begin{array}{l}\text { Compared with low }(5.8 \%) \text { and moderate } \\
(7.5 \%) \text { activity, patients with high activity } \\
\text { had higher rates of osteolysis (OR, 3.9) }\end{array}$ \\
\hline
\end{tabular}

MINORS = Methodological Index for Non-randomized Studies; LOE = level of evidence; OR = odds ratio; NR = not reported.

* Revision rate difference between high-activity (20\%) and low-activity cohorts (6\%).

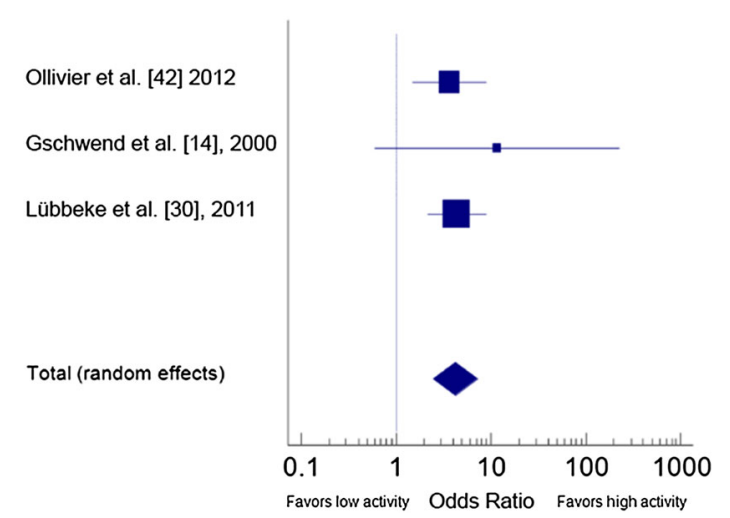

Fig. 3 The forest plot shows the odd ratios (OR) for aseptic loosening for patients with a high activity level after THA (OR, 4.24; 95\% CI, 2.46-7.31; $\mathrm{p}=0.001)$.

regarding risk factors associated with loosening thereby decreasing the strength of our conclusions. However, because our study evaluated prognostic factors, we believe that the use of retrospective studies is acceptable in performing our analysis and formulating our conclusions. Additionally, many of the studies considered did not include the raw data, so the OR of some host factors that may be associated with aseptic loosening could not be calculated. However, we think that by implementing our MINORS criteria and excluding studies that had greater than $25 \%$ loss to followup provides a basic level of evidence that allows the results of our study to be plausible. In addition, owing to the volume of the databases and the number of years spanned in many of the studies evaluated, analysis of the many changes in polyethylene processing, sterilization, implant design (especially cemented versus cementless constructs in THA), and surgical technique (which also can affect loosening rates) was not performed.
A much more accurate way to analyze these factors would be to identify a large population of patients with one implant design, surgical technique, specific type of polyethylene, and sterilization technique. Unfortunately, this is not likely to be possible; most studies by this stratification are heterogeneous and therefore, one must appreciate this as a critical limitation that should be addressed in future studies of the same factors.

In addition, aseptic loosening results from multifactorial causes, and our study did not address surgical, implant, genetic, pharmacologic, and endotoxin factors that may play a role. We focused specifically on host-related factors which can be assessed preoperatively, thus allowing surgeons to be aware of and to discuss the risks with their patients before surgery. Another important set of limitations relates to the host factors analyzed. For example, when analyzing tobacco use, we were unable to separate current from former tobacco use, thereby making it difficult 
Table 3. BMI studies

\begin{tabular}{|c|c|c|c|c|c|c|c|c|}
\hline Study & LOE & MINORS & $\begin{array}{l}\text { Number } \\
\text { of hips }\end{array}$ & $\begin{array}{l}\text { Mean age, } \\
\text { years (range) }\end{array}$ & $\begin{array}{l}\text { Mean } \\
\text { followup, } \\
\text { years } \\
\text { (range) }\end{array}$ & $\begin{array}{l}\text { Revision } \\
\text { because of } \\
\text { wear }(\%)^{\#}\end{array}$ & $\begin{array}{l}\text { Overall } \\
\text { aseptic } \\
\text { loosening } \\
\text { rate }\end{array}$ & Outcomes \\
\hline $\begin{array}{l}\text { Lubbeke } \\
\text { et al. [30] }\end{array}$ & III & 7 & 589 & NR & $5(\mathrm{NR})$ & $0.8 / 0.9$ & NR & $\begin{array}{l}\text { No association between obese BMI and risk of } \\
\text { revision }\end{array}$ \\
\hline $\begin{array}{l}\text { Munger } \\
\quad \text { et al. [37] }\end{array}$ & III & 7 & 725 & 65 (NR) & NR & NR & NR & $\begin{array}{l}\text { Increased the risk of stem loosening per } \\
\text { additional unit of BMI }(\mathrm{OR}, 1.03 ; \mathrm{p}<0.02)\end{array}$ \\
\hline $\begin{array}{l}\text { Andrew } \\
\text { et al. [2] }\end{array}$ & IV & 9 & 1059 & NR (21-94) & NR (3-5) & $1.5 / 1.3 / 0$ & NR & $\begin{array}{l}\text { Obese patients had no significant radiologic } \\
\text { changes }(\mathrm{p}>0.05)\end{array}$ \\
\hline $\begin{array}{l}\text { McLaughlin } \\
\text { et al. [34] }\end{array}$ & IV & 8 & 209 & $54(20-77)$ & $15(10-19)$ & $60 / 67.9$ & 8.3 & $\begin{array}{l}\text { No statistically significant difference was } \\
\text { identified between the obese and nonobese } \\
\text { patients regarding clinical and radiologic } \\
\text { outcomes or complications }\end{array}$ \\
\hline $\begin{array}{l}\text { Lehman } \\
\text { et al. [28] }\end{array}$ & IV & 7 & 60 & $50(17-67)$ & $2(\mathrm{NR})$ & $6.7 / 9.2$ & NR & $\begin{array}{l}\text { No statistically significant association between } \\
\text { increased BMI and need for revision. ( } 6.7 \% \\
\text { revision rate obese vs. } 9.2 \% \text { nonobese) }\end{array}$ \\
\hline $\begin{array}{l}\text { Ibrahim } \\
\quad \text { et al. [15] }\end{array}$ & IV & 6 & 179 & $66.4(33-86)$ & NR & $3.6 / 3.2$ & NR & $\begin{array}{l}\text { No association between BMI and need for } \\
\text { revision surgery (total obese: } 3.6 \% \text {; } \\
\text { nonobese: } 3.2 \% \text { ) }\end{array}$ \\
\hline $\begin{array}{l}\text { Søballe et al. } \\
{[51]}\end{array}$ & IV & 6 & 125 & $70(28-89)$ & $5(\mathrm{NR})$ & 2.1 & 2.4 & $\begin{array}{l}\text { Similar outcomes obese versus nonobese } \\
\text { (radiographic signs of loosening equally } \\
\text { common between obese vs. nonobese) }\end{array}$ \\
\hline
\end{tabular}

MINORS = Methodological Index for Non-randomized Studies; LOE = level of evidence; OR = odds ratio; NR = not reported.

\# Revision rates of obese and nonobese cohorts.

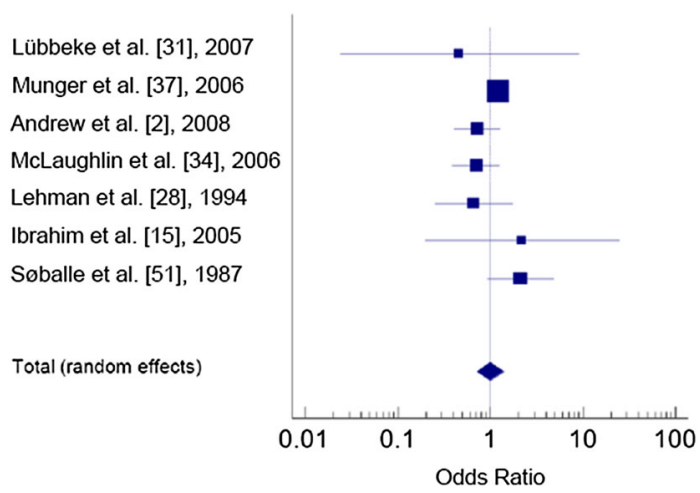

Fig. 4 The forest plot shows the odd ratios (OR) for aseptic loosening for BMI of $30 \mathrm{~kg} / \mathrm{m}^{2}$ or greater after THA (OR, 1.01; 95\% CI, 0.73-1.40; $\mathrm{p}=0.96)$.

to infer whether smoking cessation can reduce the risk of aseptic loosening. Furthermore, although many studies $[2,9,10,34,37,38,43,46,48,51,52]$ examined the role of obesity, there were not enough raw data to stratify results based on morbid obesity in THA ( $\mathrm{n}=26$ hips) $\left(\mathrm{BMI} \geq 40 \mathrm{~kg} / \mathrm{m}^{2}\right.$ ) and there was only one study [40] that specifically examined outcomes of super obesity in TKA ( $\mathrm{n}=101 \mathrm{knees})\left(\mathrm{BMI} \geq 50 \mathrm{~kg} / \mathrm{m}^{2}\right)$. Therefore, we were unable to examine an association between morbid obesity and aseptic loosening after THA or TKA.
Among modifiable risk factors, multiple factors such as high activity level $[3,14,17,30,43,44,48]$, obesity [2, 9 , $10,34,37,38,43,46,48,51,52]$, and smoking [10, 12, 16, $17,19,32,35,41]$ may be associated with an increase in the risk of aseptic loosening after THA.

Among nonmodifiable risk factors, male sex $[4,5,16$, 37, 38, 42, 46, 48, 52] and younger patient age ( $<65$ years) [1, 4-7, 12, 17, 22-25, 37, 38, 43, 46, 52, 53] have been studied for their potential association with aseptic loosening. Even though we found an association 
Table 4. Tobacco use (current and former)

\begin{tabular}{|c|c|c|c|c|c|c|c|c|}
\hline Study & LOE & MINORS & $\begin{array}{l}\text { Number } \\
\text { of hips }\end{array}$ & $\begin{array}{l}\text { Mean age, } \\
\text { years } \\
\text { (range) }\end{array}$ & $\begin{array}{l}\text { Mean } \\
\text { followup, } \\
\text { years (range) }\end{array}$ & $\begin{array}{l}\text { Revision } \\
\text { because of } \\
\text { wear }(\%)\end{array}$ & $\begin{array}{l}\text { Overall } \\
\text { aseptic } \\
\text { loosening } \\
\text { rate }\end{array}$ & Outcomes \\
\hline $\begin{array}{l}\text { Kapadia } \\
\text { et al. } \\
\text { [19] }\end{array}$ & III & 6 & 110 & $55(35-84)$ & $4(2-6)$ & $5 / 1^{+}$ & 1 & $\begin{array}{l}\text { Nonsmoker group was } 99 \% \text { ( } 1 \% \text { revision rate), } \\
\text { survivorship which was significantly higher than } \\
92 \%(5 \% \text { revision rate survivorship among the } \\
\text { smokers }(\mathrm{p}=0.0011)\end{array}$ \\
\hline $\begin{array}{l}\text { Khan } \\
\text { et al. } \\
{[21]}\end{array}$ & IV & 7 & 1767 & $69(\mathrm{NR})$ & $\mathrm{NR}$ (5 to NR) & $\begin{array}{c}0.8 / 1.5 / \\
1.3^{*}\end{array}$ & NR & $\begin{array}{l}\text { No significant difference in the revision rates } \\
\text { between nonsmokers }(0.8 \%) \text {, current smokers } \\
(1.5 \%) \text {, and exsmokers }(1.3 \%)(\mathrm{p}=0.67)\end{array}$ \\
\hline $\begin{array}{l}\text { Meldrum } \\
\text { et al. } \\
\text { [35] }\end{array}$ & IV & 6 & 165 & $61(21-83)$ & $\mathrm{NR}$ (5 to NR) & $11.8 / 1.9^{+}$ & NR & $\begin{array}{l}\text { Revision rate } 11.8 \% \text { smokers vs. } 1.9 \% \\
\text { nonsmokers; } p=0.0012\end{array}$ \\
\hline
\end{tabular}

MINORS = Methodological Index for Non-randomized Studies; LOE = level of evidence; NR = not reported.

+ Revision rates of smokers and nonsmokers; *revision rates for nonsmokers, smokers, and exsmokers.

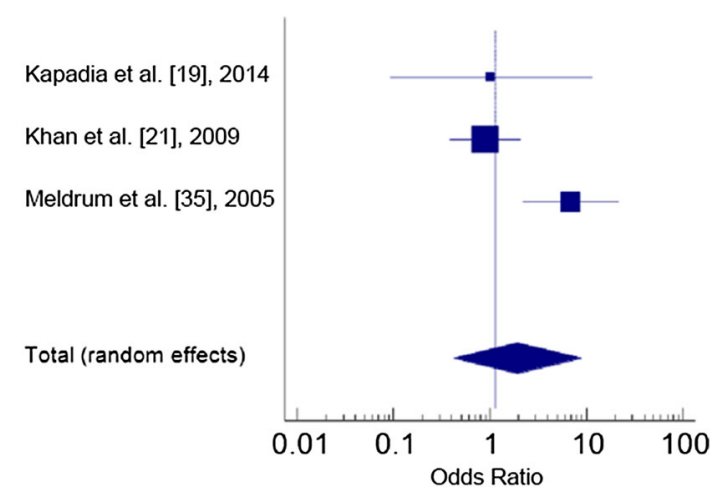

Fig. 5 The forest plot shows the odd ratios (OR) for aseptic loosening for tobacco use after THA (OR, 1.96; 95\% CI, 0.43-8.97; p = 0.39).

with male sex, we were unable to determine an association with age owing to the lack of available raw data. Furthermore, although there was no association between the risk of aseptic loosening and BMI of $30 \mathrm{~kg} / \mathrm{m}^{2}$ or greater, this finding may have been attributable to the small number of studies available to calculate the OR and CIs. Although we found no association between tobacco use (current and former) and loosening, we still believe surgeons should encourage weight loss and smoking cessation among their patients because of the well-known potential advantages to overall health.

Similar to THA, a high BMI has been associated with increased aseptic loosening rates after TKA [49]. Although we did not find an association between obesity and aseptic loosening, this may be attributable to the small cohorts in each study chosen. Therefore, any future studies regarding this potential association should have larger cohort sizes. Moreover, there are studies linking increased rates of aseptic loosening to an increased BMI [8, 11, 39, 44, 54, 56]. Conversely, there are multiple studies that have shown no association between patient obesity (BMI $\geq 30 \mathrm{~kg} / \mathrm{m}^{2}$ ) and aseptic loosening rates [13, 27, 36, 39, 57]. Although our study was unable to analyze other host factors, previous studies have associated younger age $[4,6,15,21,24,36$, $41,45,53]$, increased activity level [11, 16, 44, 52], and tobacco use [20] with increased rates of aseptic loosening. To appropriately analyze whether these host factors have an association with aseptic loosening, future studies should report their raw data regarding the incidence of aseptic loosening with each of these various factors. Moreover, it will be important to examine the role of morbid obesity and super obesity $\left(\mathrm{BMI} \geq 50 \mathrm{~kg} / \mathrm{m}^{2}\right)$ and see if these two subclassifications of obesity negatively affect implant survivorship.

It is possible that multiple interrelated factors are associated with an increased frequency of aseptic loosening. 
Table 5. TKA with obese BMI studies

\begin{tabular}{|c|c|c|c|c|c|c|c|}
\hline Study & LOE & MINORS & $\begin{array}{l}\text { Number } \\
\text { of } \\
\text { knees }\end{array}$ & $\begin{array}{l}\text { Mean age, } \\
\text { years } \\
\text { (range) }\end{array}$ & $\begin{array}{l}\text { Mean } \\
\text { followup, } \\
\text { years (range) }\end{array}$ & $\begin{array}{l}\text { Revision } \\
\text { because } \\
\text { of } \\
\text { wear } \\
(\%)\end{array}$ & Outcomes \\
\hline $\begin{array}{l}\text { Naziri et al. } \\
\text { [39] }\end{array}$ & III & 9 & 99 & $60(43-74)$ & $5(3-7)$ & $6 / 2^{*}$ & $\begin{array}{l}\text { No significant difference in implant survivorship in } \\
\text { patients }>50 \mathrm{~kg} / \mathrm{m}^{2} \text { compared with }<30 \mathrm{~kg} / \mathrm{m}^{2}(6 \% \\
\text { superobese revision rate vs. } 2 \% \text { nonobese revision rate) }\end{array}$ \\
\hline $\begin{array}{l}\text { Foran et al. } \\
\text { [11] }\end{array}$ & III & 8 & 27 & $62(36-78)$ & $15(7-18)$ & 7.4 & Obese patients had 3 times higher revision rates $(\mathrm{p}>0.05)$ \\
\hline $\begin{array}{l}\text { Griffin et al. } \\
\text { [13] }\end{array}$ & III & 7 & 73 & $68(46-82)$ & $11(10-12)$ & 7.3 & $\begin{array}{l}\text { Similar overall rates of loosening and wear between obese and } \\
\text { nonobese patients (all revisions were in nonobese group) }\end{array}$ \\
\hline $\begin{array}{l}\text { Mont et al. } \\
{[36]}\end{array}$ & III & 7 & 50 & $61(30-74)$ & $7(2-11)$ & $8 / 4^{*}$ & $\begin{array}{l}\text { Weight as an independent factor should not compromise the } \\
\text { results of TKA. ( } 8 \% \text { obese vs. } 4 \% \text { control) }\end{array}$ \\
\hline $\begin{array}{l}\text { Krushell \& } \\
\text { Fingeroth } \\
\text { [27] }\end{array}$ & IV & 7 & 39 & $67(4-81)$ & NR (5 to NR) & 5.1 & $\begin{array}{l}\text { No statistically significant difference was identified between the } \\
\text { obese and nonobese patients regarding radiolucencies }\end{array}$ \\
\hline
\end{tabular}

MINORS = Methodological Index for Non-randomized Studies; LOE = level of evidence; NR = not reported.

* Revision rates for patients with a BMI $>50 \mathrm{~kg} / \mathrm{m}^{2}$ (6\%) compared with $<30 \mathrm{~kg} / \mathrm{m}^{2}(2 \%)$.

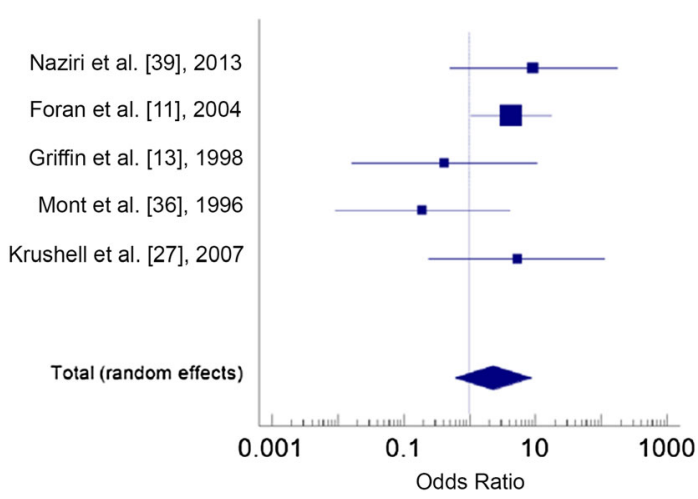

Fig. 6 The forest plot shows the odds ratios (OR) for aseptic loosening for obese BMI $\geq 30 \mathrm{~kg} / \mathrm{m}^{2}$ after TKA (OR, 2.28; 95\% CI, 0.60-8.62; $\mathrm{p}=0.22$ ).

However, the only risk factors that we found that were associated with aseptic loosening after THA were male sex and high activity level. Therefore, we believe that patients undergoing THA who regularly engage in impact sports should be informed of their increased risk for aseptic loosening and should be counseled to avoid impact sports after THA. We cannot make any recommendations regarding patients after TKA as we were unable to find any risk factors associated with loosening. Given the paucity of high-quality evidence available on this subject, we believe there is need for further studies on these factors associated with aseptic loosening with the use of newer implant designs. Furthermore, future studies should focus on whether the correction of other studied modifiable risk factors, such as tobacco use and obesity, leads to a tangible reduction in the incidence of aseptic loosening after THA or TKA.
Acknowledgments We thank Timothy Wright $\mathrm{PhD}$ (Department of Biomechanics and Biomaterials, Hospital for Special Surgery, New York, NY, USA) and Stuart Goodman MD, PhD (Division of Orthopaedics, Stanford University Medical Center, Redwood City, CA, USA) for inviting us to participate in the ABJS Carl T. Brighton Workshop on Implant Wear and Tribocorrosion of Total Joint, where this study originally was presented.

\section{References}

1. Adelani MA, Crook K, Barrack RL, Maloney WJ, Clohisy JC. What is the prognosis of revision total hip arthroplasty in patients 55 years and younger? Clin Orthop Relat Res. 2014; 472: 1518-1525.

2. Andrew JG, Palan J, Kurup HV, Gibson P, Murray DW, Beard DJ. Obesity in total hip replacement. J Bone Joint Surg Br. 2008;90:424-429.

3. Bennett D, Humphreys L, O'Brien S, Kelly C, Orr J, Beverland DE. Activity levels and polyethylene wear of patients 10 years 
post hip replacement. Clin Biomech (Bristol, Avon). 2008;23:571-576.

4. Bordini B, Stea S, De Clerico M, Strazzari S, Sasdelli A, Toni A. Factors affecting aseptic loosening of 4750 total hip arthroplasties: multivariate survival analysis. BMC Musculoskelet Disord. 2007;8:69.

5. Clauss M, Gersbach S, Butscher A, Ilchmann T. Risk factors for aseptic loosening of Muller-type straight stems: a registry-based analysis of 828 consecutive cases with a minimum follow-up of 16 years. Acta Orthop. 2013;84:353-359.

6. Dayton MR. Should age be a determining factor in total hip arthroplasty? Orthopedics. 2010;33:756-757.

7. de Kam DC, Gardeniers JW, Veth RP, Schreurs BW. Good results with cemented total hip arthroplasty in patients between 40 and 50 years of age. Acta Orthop. 2010;81:165-170.

8. Dewan A, Bertolusso R, Karastinos A, Conditt M, Noble PC, Parsley BS. Implant durability and knee function after total knee arthroplasty in the morbidly obese patient. $J$ Arthroplasty. 2009;24(6 suppl):89-94.

9. Dowdy PA, Rorabeck CH, Bourne RB. Uncemented total hip arthroplasty in patients 50 years of age or younger. J Arthroplasty. 1997;12:853-862.

10. Espehaug B, Havelin LI, Engesaeter LB, Langeland N, Vollset SE. Patient-related risk factors for early revision of total hip replacements: a population register-based case-control study of 674 revised hips. Acta Orthop Scand. 1997;68:207-215.

11. Foran JR, Mont MA, Rajadhyaksha AD, Jones LC, Etienne G, Hungerford DS. Total knee arthroplasty in obese patients: a comparison with a matched control group. J Arthroplasty. 2004;19:817-824.

12. Garcia-Rey E, Cruz-Pardos A, Garcia-Cimbrelo E. Alumina-onalumina total hip arthroplasty in young patients: diagnosis is more important than age. Clin Orthop Relat Res. 2009;467:22812289.

13. Griffin FM, Scuderi GR, Insall JN, Colizza W. Total knee arthroplasty in patients who were obese with 10 years followup. Clin Orthop Relat Res. 1998;356:28-33.

14. Gschwend N, Frei T, Morscher E, Nigg B, Loehr J. Alpine and cross-country skiing after total hip replacement: 2 cohorts of 50 patients each, one active, the other inactive in skiing, followed for 5-10 years. Acta Orthop Scand. 2000;71:243-249.

15. Ibrahim T, Hobson S, Beiri A, Esler CN. No influence of body mass index on early outcome following total hip arthroplasty. Int Orthop. 2005;29:359-361.

16. Inacio MC, Ake CF, Paxton EW, Khatod M, Wang C, Gross TP, Kaczmarek RG, Marinac-Dabic D, Sedrakyan A. Sex and risk of hip implant failure: assessing total hip arthroplasty outcomes in the United States. JAMA Intern Med. 2013;173:435-441.

17. Inoue K, Ushiyama T, Tani Y, Hukuda S. Sociodemographic factors and failure of hip arthroplasty. Int Orthop. 1999;23:330-333.

18. Jiang Y, Jia T, Wooley PH, Yang SY. Current research in the pathogenesis of aseptic implant loosening associated with particulate wear debris. Acta Orthop Belg. 2013;79:1-9.

19. Kapadia BH, Issa K, Pivec R, Bonutti PM, Mont MA. Tobacco use may be associated with increased revision and complication rates following total hip arthroplasty. J Arthroplasty. 2014;29:777-780.

20. Kapadia BH, Johnson AJ, Naziro Q, Mont MA, Delanois RE. Increased revision rates after total knee arthroplasty in patients who smoke. J Arthroplasty. 2012; 27:1690-1695.e1.

21. Khan LA, Cowie JG, Ballantyne JA, Brenkel IJ. The complication rate and medium-term functional outcome after total hip replacement in smokers. Hip Int. 2009;19:47-51.

22. Kim YH, Kook HK, Kim JS. Total hip replacement with a cementless acetabular component and a cemented femoral component in patients younger than fifty years of age. J Bone Joint Surg Am. 2002;84:770-774.
23. Kim YH, Oh SH, Kim JS. Primary total hip arthroplasty with a second-generation cementless total hip prosthesis in patients younger than fifty years of age. J Bone Joint Surg Am. 2003;85:109-114.

24. Kim YH, Park JW, Kim JS. Cementless metaphyseal fitting anatomic total hip arthroplasty with a ceramic-on-ceramic bearing in patients thirty years of age or younger. J Bone Joint Surg Am. 2012;94:1570-1575.

25. Kim YH, Park JW, Patel C, Kim DY. Polyethylene wear and osteolysis after cementless total hip arthroplasty with alumina-onhighly cross-linked polyethylene bearings in patients younger than thirty years of age. J Bone Joint Surg Am. 2013;95:10881093.

26. Kokoszka P, Staszczuk P, Redman M, Pislewski Z, Pietrzak K. [Evaluation of outcomes following total hip arthroplasty][in Polish]. Chir Narzadow Ruchu Ortop Pol. 2008;73:94-100.

27. Krushell RJ, Fingeroth RJ. Primary total knee arthroplasty in morbidly obese patients: a 5- to 14-year follow-up study. J Arthroplasty. 2007;22(6 suppl 2):77-80.

28. Lehman DE, Capello WN, Feinberg JR. Total hip arthroplasty without cement in obese patients: a minimum two-year clinical and radiographic follow-up study. J Bone Joint Surg Am. 1994;76:854-862.

29. Li G, Wu P, Xu Y, Yu Y, Sun L, Zhu L, Ye D. The effect of Lipoxin A4 on the interaction between macrophage and osteoblast: possible role in the treatment of aseptic loosening. BMC Musculoskelet Disord. 2009;10:57.

30. Lubbeke A, Garavaglia G, Barea C, Stern R, Peter R, Hoffmeyer $P$. Influence of patient activity on femoral osteolysis at five and ten years following hybrid total hip replacement. J Bone Joint Surg Br. 2011;93:456-463.

31. Lubbeke A, Stern R, Garavaglia G, Zurcher L, Hoffmeyer P. Differences in outcomes of obese women and men undergoing primary total hip arthroplasty. Arthritis Rheum. 2007;57:327334.

32. Malik MH, Gray J, Kay PR. Early aseptic loosening of cemented total hip arthroplasty: the influence of non-steroidal anti-inflammatory drugs and smoking. Int Orthop. 2004;28:211-213.

33. McKellop H, Clarke I, Markolf K, Amstutz H. Friction and wear properties of polymer, metal, and ceramic prosthetic joint materials evaluated on a multichannel screening device. J Biomed Mater Res. 1981;15:619-653.

34. McLaughlin JR, Lee KR. The outcome of total hip replacement in obese and non-obese patients at 10- to 18-years. J Bone Joint Surg Br. 2006;88:1286-1292.

35. Meldrum RD, Wurtz LD, Feinberg JR, Capello WN. Does smoking affect implant survivorship in total hip arthroplasty? A preliminary retrospective case series. Iowa Orthop J. 2005;25:17-24.

36. Mont MA, Mathur SK, Krackow KA, Loewy JW, Hungerford DS. Cementless total knee arthroplasty in obese patients: a comparison with a matched control group. J Arthroplasty. 1996;11:153-156.

37. Munger P, Roder C, Ackermann-Liebrich U, Busato A. Patientrelated risk factors leading to aseptic stem loosening in total hip arthroplasty: a case-control study of 5,035 patients. Acta Orthop. 2006;77:567-574.

38. Nashed RS, Becker DA, Gustilo RB. Are cementless acetabular components the cause of excess wear and osteolysis in total hip arthroplasty? Clin Orthop Relat Res. 1995;317:19-28.

39. Naziri Q, Issa K, Malkani AL, Bonutti PM, Harwin SF, Mont MA. Bariatric orthopaedics: total knee arthroplasty in superobese patients (BMI $>50 \mathrm{~kg} / \mathrm{m} 2$ ). Survivorship and complications. Clin Orthop Relat Res. 2013;471:3523-3530.

40. Nikolaou VS, Korres D, Lallos S, Mavrogenis A, Lazarettos I, Sourlas I, Efstathopoulos N. Cemented Muller straight stem total 
hip replacement: 18 year survival, clinical and radiological outcomes. World J Orthop. 2013;4:303-308.

41. Nixon M, Taylor G, Sheldon P, Iqbal SJ, Harper W. Does bone quality predict loosening of cemented total hip replacements? J Bone Joint Surg Br. 2007;89:1303-1308.

42. Ollivier M, Frey S, Parratte S, Flecher X, Argenson JN. Does impact sport activity influence total hip arthroplasty durability? Clin Orthop Relat Res. 2012;470:3060-3066.

43. Prakash U, Mulgrew S, Espley AJ. Effect of activity levels on polyethylene wear in Charnley low-friction arthroplasty. J R Coll Surg Edinb. 1999;44:193-196.

44. Ranawat CS, Flynn WF Jr, Saddler S, Hansraj KK, Maynard MJ. Long-term results of the total condylar knee arthroplasty: a 15-year survivorship study. Clin Orthop Relat Res. 1993;286:94-102.

45. Ren W, Markel DC, Schwendener R, Ding Y, Wu B, Wooley PH. Macrophage depletion diminishes implant-wear-induced inflammatory osteolysis in a mouse model. J Biomed Mater Res A. 2008;85:1043-1051.

46. Roder C, Eggli S, Munger P, Melloh M, Busato A. Patient characteristics differently affect early cup and stem loosening in THA: a case-control study on 7,535 patients. Int Orthop. 2008;32:33-38.

47. Sadoghi P, Liebensteiner M, Agreiter M, Leithner A, Bohler N, Labek G. Revision surgery after total joint arthroplasty: a complication-based analysis using worldwide arthroplasty registers. J Arthroplasty. 2013;28:1329-1332.

48. Schmalzried TP, Shepherd EF, Dorey FJ, Jackson WO, dela Rosa M, Fa'vae F, McKellop HA, McClung CD, Martell J, Moreland JR, Amstutz HC. The John Charnley Award: wear is a function of use, not time. Clin Orthop Relat Res. 2000;381:36-46.
49. Schroer WC, Berend KR, Lombardi AV, Barnes CL, Bolognesi MP, Berend ME, Ritter MA, Nunley RM. Why are total knees failing today? Etiology of total knee revision in 2010 and 2011. J Arthroplasty. 2013;28(8 suppl):116-119.

50. Slim K, Nini E, Forestier D, Kwiatkowski F, Panis Y, Chipponi J. Methodological index for non-randomized studies (minors): development and validation of a new instrument. ANZ J Surg. 2003;73:712-716.

51. Soballe K, Christensen F, Luxhoj T. Hip replacement in obese patients. Acta Orthop Scand. 1987;58:223-225.

52. Stihsen C, Radl R, Keshmiri A, Rehak P, Windhager R. Subsidence of a cementless femoral component influenced by body weight and body mass index. Int Orthop. 2012;36:941-947.

53. Takenaga RK, Callaghan JJ, Bedard NA, Liu SS, Klaassen AL, Pedersen DR. Cementless total hip arthroplasty in patients fifty years of age or younger: a minimum ten-year follow-up. $J$ Bone Joint Surg Am. 2012;94:2153-2159.

54. Toman J, Iorio R, Healy WL. All-polyethylene and metal-backed tibial components are equivalent with BMI of less than 37.5. Clin Orthop Relat Res. 2012;470:108-116.

55. van Raaij TM, Reijman M, Furlan AD, Verhaar JA. Total knee arthroplasty after high tibial osteotomy: a systematic review. BMC Musculoskelet Disord. 2009;10:88.

56. Vazquez-Vela Johnson G, Worland RL, Keenan J, Norambuena N. Patient demographics as a predictor of the ten-year survival rate in primary total knee replacement. J Bone Joint Surg Br. 2003;85:52-56.

57. Whiteside LA, Vigano R. Young and heavy patients with a cementless TKA do as well as older and lightweight patients. Clin Orthop Relat Res. 2007;464:93-98. 